\title{
POST-TRAUMA ROOT FRACTURE IN TEETH WITH INCOMPLETE ROOT DEVELOPMENT: A CASE REPORT
}

\author{
MEHMET SINAN DOĞAN ${ }^{1}$, DIAH AYU MAHARANI², LINDAWATI S KUSDHANY ${ }^{3}$, MELISSA ADİATMAN², \\ IZZET YAVUZ ${ }^{4 *}$
}

${ }^{1}$ Department of Pediatric Dentistry, Faculty of Dentistry, Harran University, Sanlıurfa, Türkiye. ${ }^{2}$ Department of Preventive and Public Health Dentistry, Faculty of Dentistry, Universitas Indonesia, Depok, West Java, Indonesia. ${ }^{3}$ Department of Prosthodontic, Faculty of Dentistry, Universitas Indonesia, Depok, West Java, Indonesia. ${ }^{4}$ Department of Pediatric Dentistry, Faculty of Dentistry, Dicle University, Diyarbakır, Türkiye. Email: izzetyavuz@hotmail.com

Received: 24 January 2017, Revised and Accepted: 13 July 2017

ABSTRACT

Objective: Oblique root fractures consist of multiple, angled fracture lines extending from the root canal to the periodontal membrane along the long axis of the tooth. Oblique root fractures are injuries with poor prognosis which are rarely observed in teeth in which the root development is complete.

Methods: A clinical and radiological inspection was performed of an eight-year-old patient who presented at our clinic for dental trauma. Luxation and oblique sectional root fractures in the maxillary incisors were found. The patient's root development was incomplete. He was treated with dental reposition. Fixation to the adjacent primary canine teeth was carried out using a $0.4 \mathrm{~mm}$ full circle orthodontic wire for fractured teeth with a semi-rigid splint. Stabilization of the teeth was ensured to protect the vitality of the fractured teeth. A splint was inserted under local anaesthesia and removed a month later.

Results: The absence of pathological symptoms was determined radiologically and clinically. It was shown during a radiological examination of the patient a year later that root development inthe teeth with a root fracture had continued. There were no pathological complications.

Conclusion: The current study finding of high recovery potential in young permanent teeth with root fracture is supported by those of other studies in the literature. Recovery in this case was successful because the patient presented timeously at the clinic after the trauma, there was a lack of infection, and the splint was only in situ for a month.

Keywords: Post-trauma root fracture, Oblique root fracture, Spontaneous healing, Dental splint, Incomplete root development, Young permanent teeth.

(C) 2017 The Authors. Published by Innovare Academic Sciences Pvt Ltd. This is an open access article under the CC BY license (http://creativecommons. org/licenses/by/4. 0/) DOI: http://dx.doi.org/10.22159/ajpcr.2017.v10i11.17280

\section{INTRODUCTION}

It has been reported that root fractures that occur as a result of dental trauma are more rare than those damaged in other ways. Root fractures comprise $0.5-7.0 \%$ of injuries in permanent teeth and $2.0-4.0 \%$ of injuries in milk teeth [1]. Depending on the location of the fracture line, root fractures that occur as a result of trauma are described as cervical, medium, or apical triple. Root fracture lines are classified as horizontal, oblique, vertical, and as horizontal/oblique. In addition, the type of root fracture is divided into single, complicated ( $\geq 2$ fragments) and partial [1-3].

Horizontal root fractures are relatively uncommon, comprising $3 \%$ of all dental traumas and occurring more frequently in the maxillary incisors when root development is complete. It has been reported that recovery is experienced in $80 \%$ of cases, especially when horizontal root fractures are involved [3-5]. Vertical root fractures have a poor prognosis. Of all root fractures, the prevalence of these is $2-5 \%$ [6]. The fracture can affect the entire root or part of it $[7,8]$. Root fractures in teeth with incomplete root formation are referred to as sectional root fractures. These fractures are mostly observed as a single-side fracture and continue along the thin root canal wall of the immature root $[9,10]$.

The formation of hard tissue between the fracture sections is the ideal recovery scenario for root fractures. However, other patterns of the desired recovery involve the connective tissue, the connective tissue in conjunction with calcified tissue formation, and granulation tissue formation $[1,3,11]$. It has been reported that in order for hard tissue formation to occur, the coronal fracture fragment must not be dislocated and pulp exposure should not occur. In addition, calcified tissue has frequently been observed in teeth whose root development is incomplete [12]. It has also been noted that regeneration of the pulp tissue on the same side of the fractured root section close to the pulp is similar to dentin, whereas that on the other side is similar to cement [13]. To the high recovery potential in young permanent teeth with root fracture is supported by this study.

\section{CASE REPORT}

An 8-year-old patient presented at the Department of Pediatric Dentistry owing to dental trauma. Luxation and oblique root fractures to teeth (teeth numbers 11 and 21) with incomplete root development, were demonstrated following a clinical and radiographical examination (Fig. 1). The child was treated with dental reposition. Fixation was applied to the adjacent primary canine teeth using a $0.4 \mathrm{~mm}$ full circle orthodontic wire for fractured teeth with a semi-rigid splint (Fig. 2). Stabilization of the teeth was ensured to protect the vitality of the fractured teeth. A splint was inserted under local anesthesia and removed a month later. The absence of pathological symptoms was determined radiologically and clinically. Following a radiological examination of the patient a year later, ongoing root development in the teeth with root fracture was demonstrated. Pathological complications were not observed (Fig. 3)

\section{DISCUSSION}

It has been demonstrated in the previous studies that root fractures affecting permanent dentition mostly occur in people aged 11-20 years, primarily affecting the maxillary central teeth. Root fractures are less common in teeth where the root development is incomplete than in teeth where the development is complete [9,14-16]. Root fracture occurred in the maxillary central teeth in this case, and where the root development of the teeth was incomplete. Bacterial contamination of the coronal fragment of the pulp considerably affects the recovery of 


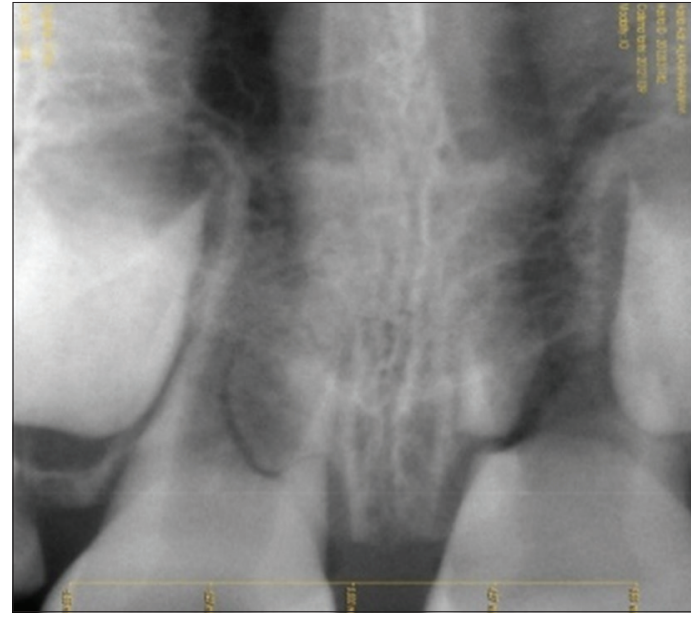

Fig. 1: Pre-treatment radiography of the patient

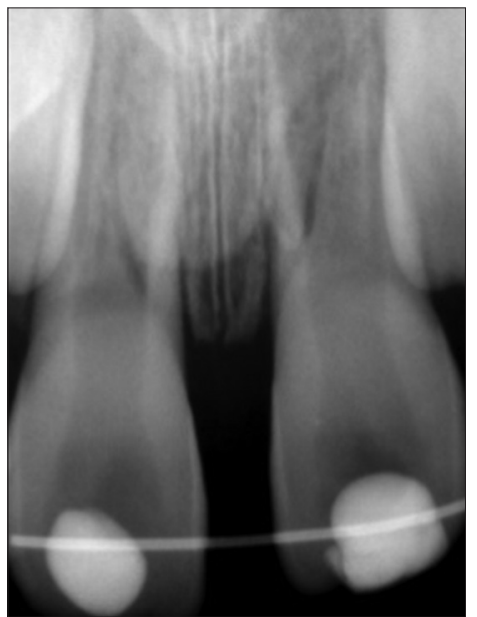

Fig. 2: A radiographic scan of the patient a month later

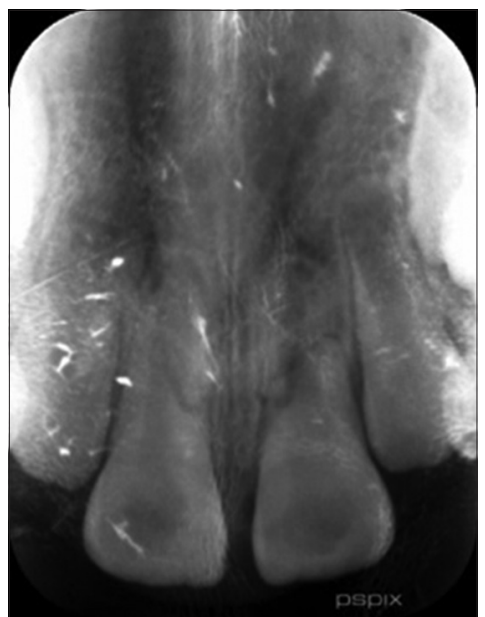

Fig. 3: A radiographic scan of the patient a year later

teeth with a root fracture. In addition, recovery is positively affected in cases where the coronal fragment has not been dislocated, and root development is incomplete. and root development is incomplete. Our case showed to high recovery potential in young permanent teeth with root fracture in this study.

Root fracture is healed by the hard tissue fusion of fragments through differentiated odontoblasts and cementoblasts in such cases [17].
Depending on the location of the root fracture and the ability of the patient to comply with recommendations, the application of a splint for 1-4 months is needed for teeth affected by root fracture due to dental trauma [18]. In our case, a splint was applied for 1 month. The patient was also advised to avoid biting and dissevering food with teeth affected by root fracture.

Feely et al. reported a statistically significant association between healing type and root fracture. They reported that a better prognosis was attributed to teeth whose root development was incomplete compared to that for teeth whose root development was complete [19]. We agree with Feely et al, due to our case treatment result. The objective of treating teeth with a root fracture is to protect pulpal vitality and to assist the tooth to regain its function. According to the findings of the previous studies, greater protection of pulp vitality should be afforded to teeth whose root development is incomplete than that given to teeth with a closed apex $[1,3,4]$. If dental vitality cannot be protected, endodontic treatment must be initiated [4]. Pathology, that might have affected dental prognosis, was not observed following clinical and radiological assessment in our case there was no any pathological sign. In addition, we saw that root development had been sustained.

In previous studies, it was reported that pulp necrosis developed in only $20-40 \%$ of permanent teeth with root fracture. The recovery of tooth function following root fracture is affected by the degree to which the root has been fractured, the status of the pulp tissue, occlusion, dislocation of the fractured parts, and the health status of the patient $[5,20,21]$. Root development was incomplete in our case. Thus, dental repositioning was performed, the distance between the fractured parts was minimized, and splinting was carried out. Fortunately, our patient did not have orthodontic problems. Accordingly, pulp vitality was preserved in the two teeth with root fractures. Flores et al. published a treatment guideline for fractures of the teeth and alveolar bone. According to this publication, good healing following an injury to the teeth and oral tissue is dependent on good oral hygiene. The patient should be instructed to brush his or her teeth with a soft brush and to rinse with chlorhexidine $0.1 \%$ as this prevents the accumulation of plaque and debris [22], and antimicrobial agents with anti-inflammatory agents advised for oral trauma cases [23,24]

Cvek et al. reported that a poor prognosis for root fracture was likely in teeth with a horizontal fracture in the cervical part of the root. Roughly $70 \%$ of these teeth had to be extracted. The poor success rate was attributed to the position of the soft tissue between the fragments as it decreased the ability of the coronal fragment to withstand the impact of mastication force [25]. Root fracture of our case was at the apical part this can be why healing has been seen.

Despite clinical success, the need for sound patient compliance and parental support to maintain oral hygiene is important [26]. Further identification of risk factors for traumatic dental injury is encouraged, and measures to prevent future trauma incidents, such as the creation of a safe physical environment for the child and a supportive social environment, are essential $[27,28]$. All of this advice from different references should be take in to consideration for healing proces.

\section{CONCLUSION}

The ideal recovery of tooth function in teeth with root fracture can be realized through suitable repositioning of the crown fragment, achieved by semi-rigid splinting and preventing the secession of the fractured fragments. In addition, patient compliance with the recommendations and ensuring oral hygiene are essential components of the recovery process.

\section{REFERENCES}

1. Andreasen JO, Andreasen FM, Mejàre I, Cvek M. Healing of 400 intraalveolar root fractures 2. Effect of treatment factors such as treatment delay, repositioning, splinting type and period and antibiotics. Dent Traumatol 2004;20(4):203-11. 
2. Fayle SA. Root fractures. In: Curzon ME, editor. Handbook of Dental Trauma. $1^{\text {st }}$ ed. Boston: Wright; 1999. p. 99-105.

3. Andreasen JO, Andreasen FM, Mejàre I, Cvek M. Healing of 400 intraalveolar root fractures 1 . Effect of pre-injury and injury factors such as sex, age, stage of root development, fracture type, location of fracture and severity of dislocation. Dent Traumatol 2004;20(4):192-202.

4. Oztan MD, Sonat B. Repair of untreated horizontal root fractures: Two case reports. Dent Traumatol 2001;17(5):240-3.

5. Ozbek M, Serper A, Calt S. Repair of untreated horizontal root fracture: A case report. Dent Traumatol 2003;19(5):296-7.

6. Andreasen JO, Andreasen FM, Skeie A, Hjørting-Hansen E, Schwartz O. Effect of treatment delay upon pulp and periodontal healing of traumatic dental injuries-a review article. Dent Traumatol 2002;18(3):116-28.

7. Testori $\mathrm{T}$, Badino $\mathrm{M}$, Castagnola $\mathrm{M}$. Vertical root fractures in endodontically treated teeth: A clinical survey of 36 cases. J Endod 1993;19(2):87-91.

8. Tamse A, Fuss Z, Lustig J, Kaplavi J. An evaluation of endodontically treated vertically fractured teeth. J Endod 1999;25(7):506-8.

9. Andreasen FM, Andreasen JO. Root Fractures in Textbook and Color Atlas of Traumatic Injuries to the Teeth. $3^{\text {rd }}$ ed. Copenhagen: Munksgaard; 1994. p. 279-311.

10. Cvek M, Andreasen JO, Borum MK. Healing of 208 intra-alveolar root fractures in patients aged 7-17 years. Dent Traumatol 2001;17(2):53-62.

11. Andreasen FM, Andreasen JO, Bayer T. Prognosis of root-fractured permanent incisors-prediction of healing modalities. Endod Dent Traumatol 1989;5(1):11-22.

12. Chang HH, Wang YL, Chen HJ, Huang GF, Guo MK. Root fracture of immature permanent incisors-a case report. Dent Traumatol 2006;22(4):218-20.

13. Welbury R, Kinirons MJ, Day P, Humphreys K, Gregg TA. Outcomes for root-fractured permanent incisors: A retrospective study. Pediatr Dent 2002;24(2):98-102.

14. Caliskan MK, Pehlivan Y. Prognosis of root-fractured permanent incisors. Endod Dent Traumatol 1996;12(3):129-36.

15. Caliskan MK, Türkün M. Clinical investigation of traumatic injuries of permanent incisors in Izmir, Turkey. Endod Dent Traumatol 1995;11(5):210-3

16. Güngör HC, Büyükgüral B, Uysal S. Root fracture in immature tooth:
Report of a case. Dent Traumatol 2007;23(3):173-6.

17. Andreasen JO, Ahrensburg SS, Tsilingaridis G. Root fractures: The influence of type of healing and location of fracture on tooth survival rates-an analysis of 492 cases. Dent Traumatol 2012;28(5):404-9.

18. Andrade ES, de Campos Sobrinho AL, Andrade MG, Matos JL. Root healing after horizontal fracture: A case report with a 13-year follow up. Dent Traumatol 2008;24(4):e1-3.

19. Feely L, Mackie IC, Macfarlane T. An investigation of root-fractured permanent incisor teeth in children. Dent Traumatol 2003;19(1):52-4

20. Majorana A, Pasini S, Bardellini E, Keller E. Clinical and epidemiological study of traumatic root fractures. Dent Traumatol 2002;18(2):77-80

21. Poi WR, Manfrin TM, Holland R, Sonoda CK. Repair characteristics of horizontal root fracture: A case report. Dent Traumatol 2002;18(2):98-102.

22. Flores MT, Andersson L, Andreasen JO, Bakland LK, Malmgren B, Barnett $\mathrm{F}$, et al. Guidelines for the management of traumatic dental injuries. I. Fractures and luxations of permanent teeth. Dent Traumatol 2007;23(2):66-71

23. Dugal S, Chakraborty S. Development and evaluation of dental films containing an antibacterial agent for the treatment of periodontitis. Int J Pharm Pharm Sci 2015;7(3):52-9.

24. Thakare VG, Joshi PA, Godse RR, Bhatkar VB, Wadegaokar PA, Omanwar SK. Antioxidant and antimicrobial activity of selected medicinal plants against human oral pathogens. Int J Pharm Pharm Sci 2016;8(9):71-8.

25. Cvek M, Tsilingaridis G, Andreasen JO. Survival of 534 incisors after intra-alveolar root fracture in patients aged 7-17 years. Dent Traumatol 2008;24(4):379-87.

26. Fidel SR, Fidel-Junior RA, Sassone LM, Murad CF, Fidel RA. Clinical management of a complicated crown-root fracture: A case report. Braz Dent J 2011;22(3):258-62

27. Oyedele TA, Jegede AT, Folayan MO. Prevalence and family structures related factors associated with crown trauma in school children resident in suburban Nigeria. BMC Oral Health 2016;16(1):116.

28. Blokland A, Watt RG, Tsakos G, Heilmann A. Traumatic dental injuries and socioeconomic position-findings from the children's dental health survey 2013. Community Dent Oral Epidemiol 2016;44(6):586-91. 